Vol. 1 No. 3 November 2021 e-ISSN : 2797-1031 | p-ISSN : 2797-0744

\title{
PENGARUH EFEKTIFIKTAS UKBM TERHADAP HASIL BELAJAR MATA PELAJARAN BIOLOGI KELAS X SISWA MAN BANGKALAN
}

\author{
ERNAWATININGSIH \\ MAN Bangkalan \\ E-mail: ernawati7072@gmail.com
}

\begin{abstract}
ABSTRAK
Penelitian ini bertujuan untuk mengetahui Efektifitas pengunaan UKBM dalam mengembangkan kognitif siswa pada Mata Pelajaran Biologi MAN Bangkalan. UKBM merupakan satuan pelajaran yang kecil yang disusun secara berurutan dari yang mudah sampai ke yang sukar. UKBM sebagai perangkat belajar bagi peserta didik untuk mencapai kompetensi pengetahuan dan keterampilan pada pembelajaran dengan menggunakan Sistem Kredit Semester (SKS). UKBM yang bagus dan menarik indikatornya adalah mampu memancing siswa untuk membaca dan berlatih, sehingga mendorong siswa rajin mempelajari dan mengerjakan uji kompetensi UKBM dan mengkonsultasikannya kepada guru jika ada kesulitan. Penelitian ini menggunakan pendekatan kualitatif deskriptif untuk menjelaskan dan menganalisis pengetahuan siswa terhadap keefektifitasan UKBM. Jenis data dalam penelitian ini yaitu data primer yang diperoleh langsung dari responden dengan metode wawancara. Subjek penelitiannya yaitu siswa MAN Bangkalan yang dipilih secara acak dengan total siswa berjumlah 6 orang dimana 3 orang siswa dengan 4 SKS, dan 3 orang siswa dengan 6 SKS. Penelitian ini dilakukan pada tanggal 20 Oktober 2021 selama 1 hari di MAN Bangkalan, dengan 8 pertanyaan seputar keefektifkan UKBM terhadap hasil belajar mata pelajaran Biologi bagi siswa. Hasil penelitiannya yaitu penggunaan UKBM sudah cukup efektif untuk proses KBM mata pelajaran Biologi Kelas X siswa MAN Bangkalan, namun siswa juga mengharapkan adanya pendukung untuk memaksimalkan UKBM tersebut yaitu dengan zoom dan google meet sehingga materi terssebut lebih dipahami oleh siswa.
\end{abstract}

Kata Kunci: Efktivitas, UKBM, Hasil Belajar, Biologi.

\section{ABSTRACT}

This study aims to determine the effectiveness of the use of UKBM in developing students' cognitive in the Biology Subject of MAN Bangkalan. UKBM is a small unit of study arranged sequentially from easy to difficult. UKBM as a learning tool for students to achieve knowledge and skill competencies in learning using the Semester Credit System (SKS). A good and interesting UKBM indicator is being able to provoke students to read and practice, thus encouraging students to study hard and work on the UKBM competency test and consult the teacher if there are difficulties. This study uses a descriptive qualitative approach to explain and analyze students' knowledge of the effectiveness of UKBM. The type of data in this study is primary data obtained directly from respondents by interview method. The research subjects were MAN Bangkalan students who were randomly selected with a total of 6 students, 3 students with 4 credits, and 3 students with 6 credits. This research was conducted on October 20, 2021 for 1 day at MAN Bangkalan, with 8 questions about the effectiveness of UKBM on the learning outcomes of Biology subjects for students. The results of the research are that the use of UKBM is quite effective for the KBM process for Biology subjects for Class X students at MAN Bangkalan, but students also expect supporters to maximize the UKBM by zooming and google meet so that the material is better understood by students.

Keywords: Effectiveness, UKBM, Learning Outcomes, Biology.

\section{PENDAHULUAN}

Kurikulum 2013 atau biasa disebut K-13 merupakan sistem pembalajaran yang saat ini digunakan di Indonesia. K-13 dianggap sebagai paradigma baru dalam pengembangannya dimana Direktorat Jenderal Pendidikan Dasar dan Menengah memprogramkan naskah 


\section{Vol. 1 No. 3 November 2021 e-ISSN : 2797-1031 | p-ISSN : 2797-0744}

pendukung yaitu UKBM (Unit Kegiatan Belajar Mandiri). UKBM merupakan satuan pelajaran yang kecil yang disusun secara berurutan dari yang mudah sampai ke yang sukar. UKBM sebagai perangkat belajar bagi peserta didik untuk mencapai kompetensi pengetahuan dan keterampilan pada pembelajaran dengan menggunakan Sistem Kredit Semester (SKS). Sistem UKBM ini termasuk baru diterapkan dan tidak semua sekolah menggunakan sistem UKBM sehingga menimbulkan banyak siswa yang merasa sulit dengan menggunakan UKBM. Hasil belajar siswa adalah kemampuan yang diperoleh anak setelah melalui kegiatan belajar. Karena belajar itu sendiri merupakan suatu proses dari seseorang yang berusaha untuk memperoleh suatu bentuk perubahan perilaku yang relatif menetap, Susanto (2015:5). Oleh karena itu guru dan siswa belum terbiasa dengan sistem UKBM. Pada mata pelajaran Biologi di MAN Bangkalan kebetulan menggunakan buku paket yaitu Quandra dan media lainnya seperti video pembalajaran yang diberikan oleh guru.

Dalam proses belajar mengajar, perkembangan kemampuan kognitif siswa merupakan salah satu indikator kualitas pendidikan. Untuk itu perlu diupayakan perbaikan pada sistem pembelajaran. Proses pembelajaran tersusun atas berbagai komponen yang saling berkaitan dan bekerjasama dalam mencapai tujuan. Suatu kegiatan belajar mengajar dapat berjalan efektif dan efisien, jika seluruh komponen yang berpengaruh dalam pembelajaran saling mendukung untuk mencapai tujuan. Kognitif merupakan salah satu aspek penting dalam perkembangan peserta didik guna menentukan keberhasilan dalam proses belajar mengajar. Guru sebagai tenaga kependidikan yang bertanggung jawab melaksanakan interaksi edukasi didalam kelas perlu memiliki pemahaman yang mendalam tentang perkembangan kognitif siswa. Dengan bekal pemahaman tersebut guru akan mampu memberikan layanan pendidikan dan dapat menyesuaikannya dengan kemampuan yang dimiliki oleh siswa, sehingga guru dapat melaksanakan proses belajar mengajar dengan baik.

Ranah kognitif berhubungan dengan kemampuan berfikir, termasuk didalamnya kemampuan menghafal, memahami, mengaplikasi, menganalisis, mensintesis dan mengevaluasi Bloom dalam Zaif (2009: 34). Pada tingkat pengetahuan, siswa menjawab pertanyaan berdasarkan hafalan saja. Pada tingkat pemahaman, siswa dituntut untuk menyampaikan apa yang sudah dipelajari dengan kata-katanya sendiri, memberi contoh suatu konsep atau prinsip. Pada tingkat aplikasi, siswa dituntut untuk dapat menerapkan apa yang dipelajari sebelumnya, yaitu dengan menerapkan prinsip dan konsep yang baru. Pada tingkat analisis, siswa diminta untuk menguraikan informasi kedalam beberapa bagian, mengemukakan apa saja hubungan sebab-akibat. Pada tingkat sintesis, siswa harus mampu menghasilkan sebuah cerita, komposisi, hipotesis atau teorinya sendiri dan mensintesiskan pengetahuannya. Pada tingkat evaluasi, siswa mengevaluasi informasi seperti bukti, sejarah, editorial dan teoriteori yang termasuk didalamnya. Tujuan aspek kognitif berorientasi pada kemampuan berfikir yang mencakup kemampuan intelektual yang lebih sederhana, yaitu mengingat, sampai pada kemampuan memcahkan masalah yang menuntut siswa untuk menghubungkan dan menggabungkan beberapa ide, gagasan, metode atau prosedur yang dipelajari untuk memecahkan suatu masalah. Menurut Sumarto ada beberapa hal yang mempengaruhi perkembangan kognitif siswa, yaitu: 1) Bertambahnya informasi yang disimpan (dalam otak) seseorag, sehingga dapat berfikir reflektif. 2) Banyaknya pengalaman dari latihan-latihan memecahkan masalah, sehingga seseorang dapat berfikir profesional. 3) adanya kebebasan berfikir menimbulkan keberanian seseorang dalam menyusun hipotesis. Kebebasan menjajaki masalah secara keseluruhan dan menunjang keberanian anak memecahkan masalah serta menarik kesimpulan.

Ada dua jenis pola pembelajaran Sistem Kredit Semester (SKS) yang ditawarkan yaitu pola SKS reguler (6 semester) dan pola SKS akselerasi (4 semester). Pada Permendikbud no 158 tahun 2014 dijelaskan bahwa anak dengan kecepatan belajar diatas rata-rata (ditandai dengan hasil task commitment dan creativity test yang tinggi) dapat menempuh 1 jam pembelajaran dengan durasi 30 menit, sementara kelas reguler durasi perjam pelajaran 45 menit (SMA), dengan demikian anak-anak yang kecepatan belajarnya diatas rata-rata dapat 
menempuh pendidikan selama 2 tahun atau 4 semester. UKBM yang bagus dan menarik indikatornya adalah mampu memancing siswa untuk membaca dan berlatih, sehingga mendorong siswa rajin mempelajari dan mengerjakan uji kompetensi UKBM dan mengkonsultasikannya kepada guru jika ada kesulitan. Kegiatan pembelajaran yang mendidik dan dialogis UKBM yang bermuara pada perkembangan kecakapan yang dikenal dengan 4C (critical, thingking, creativity, collaboration, communication) atau berfikir kritis, bertindak kreatif, bekerjasama dan berkomunikasi. Untuk itu seluruh proses berfikir harus dikembangkan dalam satu kesatuan proses psikologis-pedagogis secara utuh. Bersifat terapan pada tingkat berfikir analisis (C4), evaluasi (C6) dan kreasi (C7) dalam taksonomi bloom. Suasana dan proses kegiatan pembelajaran merupakan kondisi menentukan keberhasilan UKBM, untuk itu pembelajarannya harus dirancang secara menarik, dinamis, merangsang, menginspirasi sekaligus meyakinkan siswa bahwa kompetensi yang sedang dipelajari dapat dikuasai dengan mudah, sederhana dan bermakna untuk kehidupan.

UKBM Biologi MAN Bangkalan secara umum digunakan guru dalam evaluasi belajar siswa, siswa dituntut untuk aktif dalam proses pembelajaran, siswa secara penuh dapat mengambil bagian dalam setiap aktivitas pembelajaran, siswa mempunyai kesempatan untuk memanfaatkan secara penuh pengetahuan dan keterampilannya dalam waktu yang cukup, terbina saling pengertian baik antara guru dengan siswa ataupun siswa dengan siswa. jadi untuk proses transfer of knowledge yang dilakukan secara langsung oleh guru yaitu disampaikan diawal pembelajaran dan juga penguatan diakhir pembelajaran. Peran guru dikelas lebih dominan sebagai fasilitator dan evaluator. Atas dasar pemikiran itulah peneliti ingin membuktikan apakah Unit Kegiatan Belajar Mandiri (UKBM) dapat mengembangkan kognitif siswa? Oleh karena itu, peneliti melakukan penelitian dengan judul "Efektifitas Penggunaan Unit Kegiatan Belajar Mandiri (UKBM) dalam Mengembangkan Kognitif Siswa pada Mata Pelajaran Biologi di MAN Bangkalan.

Menurut penelitian sebelumnya yang dilakukan Imamatul (2019:7) diketahui bahwa dalam pembelajaran PAI di SMA Negeri 3 Sidoarjo sudah memberlakukan Unit Kegiatan Belajar Mandiri (UKBM) dalam proses belajar mengajar setiap hari. Dimana setiap siswa dituntut untuk menyelesaikan UKBMnya secara mandiri ataupun dikerjakan secara kelompok, dalam proses pengerjaan ada beberapa kendala yang dihadapi siswa, dikarenakan setiap siswa memiliki tingkat kecerdasan dan keterampilan yang berbeda. Dalam satu kelas ada yang sangat rajin dan cepat menyelesaikan UKBM ada juga siswa yang lambat dalam mengerjakan UKBM, itu berakibat pada guru yang harus dengan bijak dan dinamis dalam menyikapi siswa yang berbeda-beda kemampuannya.

Berdasarkan uraian diatas, permasalahan yang akan diteliti yaitu mengenai Keefektifan pengunaan UKBM dalam mengembangkan kognitif siswa pada Mata Pelajaran Biologi MAN Bangkalan. Adapun tujuan yang hendak dicapai dalam penelitian ini adalah mengetahui Efektifitas pengunaan UKBM dalam mengembangkan kognitif siswa pada Mata Pelajaran Biologi MAN Bangkalan.

\section{METODE PENELITIAN}

Penelitian ini menggunakan pendekatan kualitatif deskriptif. Penelitian ini digunakan untuk menjelaskan dan menganalisis fenomena, peristiwa, dinamika sosial, sikap kepercayaan, dan persepsi seseorang atau kelompok terhadap sesuatu. Jenis data dalam penelitian ini yaitu data primer yang diperoleh langsung dari responden. Metode pengumpulan data yang digunakan yaitu metode wawancara. Subjek penelitiannya yaitu siswa MAN Bangkalan yang dipilih secara acak. Hasil wawancara kemudian dianalisis selama 1 minggu untuk memperoleh kesimpulan akhirnya.

\section{HASIL DAN PEMBAHASAN}

Penelitian ini dilakukan selama 1 hari di MAN Bangkalan. Berikut merupakan uraian deskripsi responden penelitian, yaitu: 
Vol. 1 No. 3 November 2021 e-ISSN : 2797-1031 | p-ISSN : 2797-0744

- Gambaran Umum Objek Penelitian

Tabel 1. Gambaran Umum Objek Penelitian

\begin{tabular}{|c|c|}
\hline Lokasi Penelitian & MAN Bangkalan \\
\hline Waktu Penelitian & 20 Oktober 2021 \\
\hline Jumlah Pertanyaan & 8 Pertanyaan \\
\hline Jumlah Responden & 10 siswa \\
\hline
\end{tabular}

- Responden Penelitian

Berikut merupakan rincian siswa yang menjadi responden penelitian:

Tabel 2. Responden Penelitian

\begin{tabular}{|c|c|}
\hline Jumlah Responden & Sistem Kredit Semester \\
\hline 5 Siswa & 4 SKS \\
\hline 5 Siswa & 6 SKS \\
\hline
\end{tabular}

Berdasarkan hasil wawancara dan hasil analisis diketahui bahwa:

1. Beberapa siswa mengatakan bahwa pembalajaran UKBM sudah efektif, namun beberapa juga berpendapat bahwa dengan belajar mandiri mereka merasa kesulitan memahami materi yang diberikan.

2. Siswa merasa terbantu dengan adanya UKBM, karena mereka merasa dipermudah dengan rangkuman materi yang diberikan, karena didalam UKBM sudah tercantum KD tujun pembelajaran, materi, dan langkah-langkah kegiatan belajar juga latihanlatihan serta penutup yang merupakan rangkuman dari keseluruhan materi. Namun, apabila ada pertanyaan diluar UKBM siswa masih diminta untuk mencari alternatif pembelajaran lainnya misalnya melalui google ataupun youtube dan tidak bisa bertanya secara langsung pada guru yang bersangkutan.

3. Siswa mengatakan bahwa ketika mereka harus belajar secara mandiri (online) mereka merasa membutuhkan tempat yang nyaman dan kondusif yang tidak mengganggu konsentrasi mereka karena sebagian siswa mengaku merasa terganggu ketika belajar mandiri.

4. Sinyal dan kuota internet masih menjadi kendala utama para ketika pembelajaran online. Disusul dengan perangkat pendukung seperti laptop dan hp yang digunakan selama pembelajaran dimana itu semua membutuhkan ruang penyimpanan yang besar dikarekan para siswa juga harus menyimpan berbagai materi yang diberikan oleh guru mata pelajaran.

5. Hampir seluruh siswa lebih memilih untuk pembelajaran secara tatap muka dibandingkan secara mandiri. Mereka beralasan bahwa mereka langsung dapat bertanya hal-hal yang kurang dimengerti. Alasan lainnya karena mereka dapat melakukan praktikum secara langsung dimana itu menjadi hal yang seru bagi mereka.

6. Ketika ditanya media pembelajaran online yang efektif, kebanyakan siswa lebih memilih pembelajaran dengan zoom ataupun gmeet dengan alasan bisa langsung berkomunikasi dengan guru pembimbingnya dan juga menggunakan UKBM, sehingga proses pembelajarannya lebih sistematik.

Berdasarkan hasil wawancara diatas dapat diketahui bahwa penggunaan UKBM sudah cukup efektif untuk siswa.

Tabel 3. Responden Penelitian dan Hasilnya

\begin{tabular}{|c|c|c|}
\hline Jumlah Responden & Sistem Kredit Semester & Hasil \\
\hline 5 Siswa & 4 SKS & \multirow{2}{*}{$\begin{array}{l}\text { UKBM cukup efektif untuk hasil } \\
\text { belajar siswa }\end{array}$} \\
\hline 5 Siswa & $6 \mathrm{SKS}$ & \\
\hline
\end{tabular}


Hal ini juga diperkuat dengan rangkuman nilai siswa yang menjadi responden penelitian, sebagai berikut:

Tabel 4. Rekapan Nilai Siswa yang Menjadi Responden

\begin{tabular}{|c|c|c|c|}
\hline No. & SKS & $\begin{array}{c}\text { Nilai sebelum } \\
\text { menggunakan } \\
\text { UKBM }\end{array}$ & $\begin{array}{c}\text { Nilai setelah } \\
\text { menggunakan } \\
\text { UKBM }\end{array}$ \\
\hline 1. & 4 & 85 & 90 \\
\hline 2. & 4 & 84 & 87 \\
\hline 3. & 4 & 84 & 88 \\
\hline 4. & 4 & 83 & 88 \\
\hline 5. & 4 & 84 & 87 \\
\hline 6. & 6 & 83 & 87 \\
\hline 7. & 6 & 80 & 85 \\
\hline 8. & 6 & 78 & 86 \\
\hline 9. & 6 & 77 & 86 \\
\hline 10 & 6 & 78 & 87 \\
\hline
\end{tabular}

Dari tabel diatas maka peneliti menarik kesimpulan bahwa menggunakan UKBM dikayakan cukup efektif untuk proses daring dan PTM untuk materi teori biologi. Dengan melihat perbedaan nilai yg diperoleh juga hasil dari hari wawancara yg dilakukan siswa. Dengan adanya UKBM siswa terbantu dalam proses KBM karena dalam UKBM sudah tercantum KD, Tujuan Pembelajaran, Materi dan langkah langkah kegiatan belajar serta latian latian yang bisa melatih siswa untuk lebih mendalami materi. Di UKBM juga terdapat Penutup yang merupakan rangkuman dari seluruh materi.

\section{Pembahasan}

Melalui hasil analisis wawancara yang telah dilakukan dapat dikatakan bahwa proses pembelajaran Biologi dengan menggunakan UKBM diketahui bahwa siswa mampu belajar secara mandiri dengan rangkuman materi yang sudah lengkap dan jelas dimana siswa harus berusaha lebih keras untuk mempelajari materi tersebut. Pemberian materi secara UKBM dapat dikatakan sudah cukup efektif untuk materi teori, namun untuk praktikum dinilai kurang sebab siswa tidak bisa melakukan praktikum mandiri dirumah bukan secara langsung di dalam laboratorium. Siswa juga memberikan pendapat bahwa belajar secara mandiri membutuhkan konsentrasi yang lebih untuk tetap fokus selama belajar online dengan memilih tempat belajar yang nyaman dan kondusif. Adapun kendala yang dihadapi siswa sebagain besar terkiat dengan dengan masalah sinyal dan kuota yang harus selalu stabil selama proses belajar serta beberapa sarana pembelajaran dengan memori penuh sehingga sulit di akses dikarenakan banyaknya materi yang harus disimpan. Selian itu siswa juga mengeluhkan kendala ketika mengakses aplikasi E-learning karena UKBM terdapat didalam aplikasi E-learning seperti saat adanya pembaruan. Hampir seluruh siswa lebih memilih pembelajaran tatap muka dibandingkan dengan online, dikarenakan siswa langsung dapat bertanya hal-hal yang kurang dimengerti dan dapat melakukan praktikum secara langsung. Pemberian materi secara langsung/PTM menurut siswa dinilai lebih efektif dibandingkan secara online, namun siswa merasa terbantu dengan adanya UKBM dibandingkan tanpa adanya UKBM karena didalam UKBM sudah tercantum KD tujuan pembelajaran, materi, dan langkah-langkah kegiatan belajar juga latihan-latihan serta penutup yang merupakan rangkuman dari keseluruhan materi. Kemudian kebanyakan siswa lebih memilih pembelajaran dengan zoom ataupun gmeet dengan alasan bisa langsung 
berkomunikasi dengan guru pembimbingnya dan menggunakan UKBM, sehingga proses pembelajarannya lebih sistematik.

Hasil penelitian ini yaitu UKBM sudah cukup efektif terhadap hasil belajar mata pelajaran Biologi siswa kelas X MAN Bangkalan, sehingga relevan dengan penelitian yang dilakukan oleh Musyarofah (2018) menyimpulkan bahwa penggunaan UKBM efektif dalam mengembangkan kognitif siswa pada mate pelajaran PAI di SMAN 3 Sidoarjo. Didukung dengan penelitian lainnya yang dilakukan oleh Sertiawati \& Ruslika (2020) dengan kesimpulan bahwa penerapan UKBM dapat mempengaruhi hasil belajar siswa pada mata pelajaran Bahasa Jepang.

\section{KESIMPULAN}

Berdasarkan hasil analisis wawancara yang dilakukan di MAN Bangkalan, peneliti menarik kesimpulan yaitu:

1. Penggunaan UKBM di MAN Bangkalan sudah baik, berdasarkan dari hasil analisis wawancara yang dilakukan. Dikarenakan beberapa sebab yang mendasari UKBM bisa berjalan dengan baik apabila diterapkan di MAN Bangkalan yaitu fasilitas dari guru yang bersangkutan sudah cukup memadai, UKBM yang menarik minat belajar siswa, komponen UKBM yang mendukung siswa agar aktif dan kreatif dalam pembelajaran, antusiasme belajar siswa yang lumayan tinggi dan lain- lainnya.

2. Melalui wawancara secara langsung kepada siswa diketahui bahwa penggunaan UKBM sudah cukup efektif untuk hasil belajar mata pelajaran Biologi Kelas X siswa MAN Bangkalan, namun siswa juga mengharapkan adanya pendukung untuk memaksimalkan UKBM tersebut yaitu dengan zoom dan google meet sehingga materi tersebut lebih dipahami oleh siswa.

\section{DAFTAR PUSTAKA}

Arifin. (2011). Metode Penelitian Kualitatif, Kuantitatif, dan R\&D. Bandung: Alfabeta.

Direktorat Pembinaan Sekolah Menengah Atas, Direktorat Jenderal Pendidikan Dasar dan Menengah Kementrian Pendidikan dan Kebudayaan. (2017). Panduan Pengembangan Unit Kegiatan Belajar Mandiri. Jakarta.

Imamatul, M. (2019). Efektifitas Penggunaan Unit Kegiatan Belajar Mandiri (UKBM) DALAM Mengembangkan Kognitif Siswa pada Mata Pelajaran PAI di SMA Negeri 3 Sidoarjo. Skripsi. UIN Sunan Ampel Surabaya.

Permendikbud Republik Indonesia Nomor 69. (2013). Tentang Kerangka Dasar dan Struktur Kurikulum Sekolah Menengah Atas/Madrasa Aliyah. Tersedia dalam: https://www.kemdikbud.go.id/main/blog/2018/06/kemendikbud-berikanbantuanpendampingan-kurikulum-2013

Ruslika, A. D., Ai Sumirah Sertiawati. (2020). Pengaruh Penerapan UKBM Terhadap Hasil Belajar Mata Pelajaran Bahasa Jepang Siswa SMA. Jurnal Program Studi Sastra Jepang, Volume 9 No. 1.

Susanto, A. (2015). Teori Belajar dan Pembelajaran di Sekolah Dasar. Jakarta: Prenada Media. Zaif. (2009). Ranah Penelitian Kognitif, Afektif, dan Psikomotorik. (Online) Tersedia dalam: http://zaifbio.wordpress.com/2009/11/15/ranah-penilaian-kognitif-afektif-danpsikomotorik/ 